\title{
DESLOCAMENTOS IDENTITÁRIOS E NOMEAÇÃO NO ROMANCE CIRCLE OF AMBER
}

Marcia Sipavicius Seide (UNIOESTE)

Resumo: A nomeação e as renomeações são recursos importantes para a representação literária dos movimentos migratórios e as mudanças de identidade do sujeito migrante. Tendo isto em vista, analisamse, neste artigo, os deslocamentos identitários que são indiciados ou fomentados pelos nomes de alguma das personagens do romance Circle of Amber escrito pela lituana-australiana Jura Reilly e publicado em 2016. Após apresentação da autora e do romance com um todo, analisa-se um recorte que foca as nomeações de quatro personagens: Ella, Algimantas Kelmas, Ernestas e Gaila. A análise apresentada mostra os deslocamentos indiciados pela renomeação, os quais ocorrem por apagamento voluntário ou imposto da origem étnica dos nomeados, assédio moral relacionado com trocadilhos com o nome, e também por convergência entre o significado do nome e as características da personagem ou com o seu destino. A análise também mostra que, apesar da confirmação da caracterização da personagem pelo significado etimológico do nome ser um recurso clássico em romances de língua inglesa, esse recurso também tem relação com as crenças lituanas sobre os nomes de pessoa. Por focar os nomes próprios de personagens ficcionais, a pesquisa apresentada neste artigo se insere na Antroponomástica Literária, campo da Onomástica na qual os estudos linguísticos se unem aos literários em perspectiva interdisciplinar.

Palavras-chave: Antroponomástica literária; Literatura australiana; Literatura migrante; Migração lituana.

Abstract: Naming and renaming are important resources for the literary representation of migratory movements and changes in the identity of the migrant subject. Having this in mind, this article analyzed the identitary displacements that are pointed out or fomented by the names of some of the characters from the novel Circle of Amber written by Lithuanian-Australian Jura Reilly and published in 2016. In the first section there is an introduction of author to Brazilian readers, in the second, there is a description of the novel as a whole, and, in the third, analysis of collected excerpts from the novel that focuses 
on the nominations of four characters: Ella, Algimantas Kelmas, Ernestas and Gaila. The analysis presented shows the displacements indicated by renaming processes that results in voluntary or mandatory deletion or $f$ the ethnic origin of the nominees, moral harassment related to puns with the name, and also convergence between the meaning of the name and the characteristics of the character or his or her destiny. The analysis also shows that although confirmation of the character's characterization by the etymological meaning of the name is a classic feature in English-language novels, this feature is also related to the Lithuanian beliefs about person names. By focusing on the names fictional characters, the research presented in this article is part of the Literary Anthroponomastics, field of Onomastics in which linguistic studies join with literary in an interdisciplinary perspective.

Keywords: Literary anthroponomastics; Australian literature; Migrant literature; Lithuanian migration.

\section{INTRODUÇÃO}

A caracterização e a evolução das personagens são características fundamentais do romance. Um dos recursos utilizados para tanto é a nomeação. Quando se trata de analisar obras literárias que representam simbolicamente os movimentos migratórios e as consequentes mudanças de identidade do sujeito migrante decorrentes dos deslocamentos espaciais, culturais e linguísticos a que é submetido, é fundamental compreender como o processo de nomeação e renomeação das personagens indiciam esses deslocamentos identitários. Este é especialmente o caso dos romances que problematizam o nome do migrante e/ ou de seus descendentes. Tendo isso em vista, analiso, neste artigo, os deslocamentos identitários que são indiciados 
ou fomentados pelos nomes das personagens no romance Circle of Amber, escrito pela lituana-australiana Jura Reilly e publicado em 2016.

Adoto a concepção de identidade proposta por Zygmunt Bauman, a de identidade enquanto "um grito de guerra usado numa luta defensiva: um indivíduo contra o ataque de um grupo, um grupo menor e mais fraco e por isso ameaçado contra uma totalidade maior dotada de mais recursos" (2015, p.83). A adoção desse ponto de vista se explica pelo fato de, assim como as personagens do romance, o sujeito que se desloca precisar criar e defender uma identidade que the seja própria ou ao menos tolerável, para o que se fazem necessárias reiteradas perfomances de modo a tentar conseguir para si uma identificação condizente com as crenças pré-concebidas sobre si. Assim, muitas vezes, um indivíduo migrante pode se sentir cerceado pelo preconceito dos nativos, pelo modo como eles o classificam, categorizam e identificam. $O$ que se afirmou sobre um indivíduo também é válido para o grupo de migrantes do qual o sujeito faz parte.

Em contextos migratórios, as características que o indivíduo acreditava que lhe eram imanentes fazendo parte do que seria essencial ao seu próprio ser precisam ser recuperadas, reconstruídas ou reinventadas. ${ }^{1}$ Isso acontece

1 Sabe-se, a partir de estudiosos como Stuart Hall (2006), que o sujeito pós-moderno não 
em decorrência do deslocamento a que é submetido. No local de onde veio ele tinha uma história, amigos, familiares e era conhecido, já no local onde está, ele é um desconhecido, uma pessoa anônima sobre a qual pouco se sabe. Concomitantemente a esse despojamento de si mesmo, outros traços lhe são atribuídos por seus interlocutores, em decorrência de estereótipos e preconceitos e será preciso encontrar uma maneira de se desvencilhar dessas conotações sociais negativas. Essa necessidade de ação motivou Bauman, sociólogo polonês, a conceber a identidade como algo a ser cotidianamente conquistado mediante ações, com inclusão das ações discursivas, isto é, explicitando por aquilo que é dito e também por seu comportamento linguístico, como gostaria de ser avaliado pelo outro. (2015, p.83).

Nesses embates em que a identidade do sujeito longe de ser algo garantido, é algo a ser conquistado e defendido, é que ocorrem os deslocamentos identitários mediante os quais a imagem de si perde o foco e a pessoa deixa de ser vista como ela mesma se vê ou gostaria de ser vista. A negação pelo outro daquilo que o indivíduo julga ser essencial a sua identidade, sociologicamente, é a negação de igualdade que seria necessária para certas pessoas serem aceitas

apresenta uma essência una e imutável, tendo em vista a fragmentação e o descentramento identitário a que está sujeito, o que se descreve aqui é a crença que se tem a respeito da identidade a partir do senso comum da maioria das pessoas. 
num determinado um grupo social o qual estabelece quem são os insiders (os estabelecidos) e os outsiders (os forasteiros). Como observaram Norbert Elias e Jonh L. Scotson,

as desigualdades entre grupos e indivíduos estão entre as marcas distintivas recorrentes das sociedades humanas. Por que isso acontece é algo que ainda precisamos esclarecer (...) Ao que parece, quase todos os grupos humanos tendem a perceber determinados outros grupos como pessoas de menor valor do que eles mesmos. O grau de estigmatização pode variar de um caso para o outro, e as ações que devem tornar claro para o grupo outsider o fato de seus membros serem um objeto de maior desprezo podem ser ruidosas e bárbaras, ou aparecerem em uma tonalidade mais amena. Seja como for, relações estabelecidos outsiders têm sempre algo em comum. (ELIAS, SCOTSON, 2000, p.199)

Muitas são as ações que podem promover o (re) estabelecimento de relações identitárias, entre elas, foco a representação literária das práticas que se relacionam ao nomear a si e ao outro, ao chamar-se a si mesmo e ao ser chamado pelos outros em contextos migratórios na obra Circle of Amber.

O nome que se recebe ao nascer e que fica registrado em cartório é o nome civil, composto pelo prenome e pelo sobrenome. O apelido, por sua vez, se diferencia do nome 
civil por não ser oficial, e poder ser atribuído por outras pessoas e não apenas aos progenitores ao nomeado. Quando o apelido indica uma característica física ou psicológica da pessoa nomeada, ele se chama alcunha; já quando se trata de uma forma derivada (em geral por abreviação) do prenome da pessoa, o nome recebe o termo técnico de hipocorístico (SEIDE, 2008). Esses e outros tipos de nomes próprios de pessoa, os antropônimos, são estudados por uma disciplina chamada Antroponomástica, que faz parte de uma área interdisciplinar da linguística conhecida como Onomástica (SEIDE, 2016).

Uma vez que a pesquisa apresentada neste artigo foca os nomes próprios de personagens, ela se insere na Antroponomástica Ficcional: disciplina que se dedica ao estudo dos nomes próprios de personagens - campo que une os estudos linguísticos aos literários em relações que podem variar da multidisciplinaridade à transdisciplinaridade (SEIDE, 2016).

Na primeira seção deste artigo, apresento, aos leitores brasileiros, a autora do romance. Na segunda, sintetizo o enredo de modo breve e o contextualizo historicamente. $\mathrm{Na}$ terceira seção, apresento e analiso os trechos do romance nos quais os deslocamentos identitários são evidenciados 
por meio dos antropônimos. Por fim, nas considerações finais, sintetizo os resultados obtidos e aponto outras perspectivas de pesquisa. Ao longo do artigo, são feitas citações em língua estrangeira as quais estão traduzidas por mim em nota de rodapé logo após as citações.

\section{SOBRE A AUTORA DO ROMANCE}

Circle of Amber (Círculo de Âmbar) é o primeiro romance de Jura Reilly (seu nome oficial é Jūratè Vitkūnaitė-Reilly). Ela nasceu em Adelaide, na Austrália, no dia 11 de julho de 1952 de pais lituanos que para lá migraram como refugiados da Segunda Guerra Mundial. Passou sua infância e adolescência participando de atividades promovidas pela comunidade lituana na Austrália em obediência às orientações de seus pais. Ela e seus dois irmãos frequentaram a escola semanal de língua lituana (Saturday School), grupos de dança e música folclóricas lituanas e de escoteiros descendentes de lituanos.

Após completar seus estudos superiores na Universidade de Adelaide em Inglês e Política Internacional, casou-se com Teddy Reilly e se mudou para o estado de Victoria, no sul do país, onde cursou licenciatura em inglês no Rusden Teachers College. Jura Reilly foi professora de Inglês e de História por 35 anos e se especializou em Administração escolar na Universidade Geelong's Deakin.

2 As informações sobre sua biografia e bibliografia foram obtidos por relato pessoal escrito em língua inglesa e enviado por email pessoal no dia 02 de novembro de 2018. 
Nessa época, além de se dedicar à profissão e à família, ela atuou em prol da comunidade lituana na Austrália: em 1984, ela reinaugurou a escola de língua lituana da comunidade lituana de Geelong e colaborou com o programa de rádio lituano desde então. A partir de 2014, ela começou a divulgar as atividades da comunidade e a congregar lituanos e descendentes de lituanos anglófonos utilizando o Facebook. Ela é fundadora do grupo de Facebook Baltica, da Austrália, é administradora das páginas de Facebook VilNews e The National American Hall of Fame, além de ser membro de outros grupos relacionados à Lituânia como o The Lithuanian Group que congrega lituanos e descendentes de lituanos de várias partes do mundo.

O Brasil está entre os países onde vivem lituanos e descendentes de lituanos. Eles vieram em maior número para cá nas primeiras décadas do século passado, mas o país também abrigou algumas famílias de refugiados da Segunda Guerra Mundial ao final da década de 1940 e início de 1950. A maior parte dos lituanos e descendentes vive no estado de São Paulo, no qual há uma comunidade lituana na Vila Zelina, bairro que fica na macrorregião de Vila Prudente, zona leste de São Paulo. (SEIDE, 2018a, SEIDE, 2018b).

Jura (como irei chamá-la doravante) teve, também, papel de destaque no ensino de língua inglesa na Lituânia: 
em 1991, o Ministro de Educação da Lituânia a convidou para dar aulas de inglês como segunda língua em vários colégios. Depois dessa missão de docência, ela retornou quatro vezes ao país como consultora. Outra atividade em que se destaca é a de ourives: ela é habilidosa na criação, customização e reutilização de jóias, a maioria feitas com âmbar, pedra preciosa ${ }^{3}$ mencionada no título do seu primeiro romance.

Sua carreira literária começou em 1983 quando foi publicado um livro de poesias chamado Lithuanian Lady (Uma senhora lituana). Trinta anos depois, em 2013, foi publicada sua segunda obra: uma tradução da língua lituana para a língua inglesa de um livro de memórias escrito por seu tio enquanto durou o exílio forçado na Sibéria, longos 37 anos. A Sibéria é uma região da Rússia que se estende até as fronteiras com o Cazaquistão e a China, em 1940 e 1941 eram para lá deportadas as pessoas consideradas prejudiciais ao regime soviético, suas famílias também eram expulsas, mas viviam em campos de exílio separados.

Essa tradução recebeu o título de A Wolf At Our Door (Um lobo à nossa porta). Uma versão em lituano dela foi lançada em Kaunas, na Lituânia. O livro também foi traduzido à língua russa e parte dele formou uma coletânea chamada Histórias

3 Na verdade, o material é uma resina fossilizada de árvore, não se trata de um mineral, contudo, se considera o âmbar tão precioso quanto uma pedra preciosa. 
da Sibéria, que foi traduzida para a língua espanhola. Três anos depois, em 2016 foi publicado o Circle of Ambar, classificado pela autora como sendo um romance histórico inspirado na vida de sua bisavó Madgalena Vilkienè. Outro romance histórico foi publicado 2018, chama-se Sylvia's Book Smuggler (O traficante de livros de Silvia) e foi inspirado na vida de seu bisavô paterno Tomas Žičkauskas, que foi professor e, em 1918, época de luta pela Independência da Lituânia do czarismo russo, traficava livros ${ }^{4}$ em Marijampolé, na Lituânia.

\section{SÍNTESE DO ROMANCE E CONTEXTUALIZAÇÃO HISTÓRICA}

Sobre o romance, a autora conta que fez muitas pesquisas em websites para dar vida às épocas nas quais se passa o romance, além de se inspirar em suas memórias e vivências. Para ela, o romance apresenta duas partes: a que se passa na Lituânia e a que se desenvolve na Austrália. Na primeira parte, Jura procurou descrever fielmente como era a vida na vila fictícia de Ventuva ao final do século XX, localizada às margens do rio que faz divisa com a Letônia. Essa parte da obra termina com a Segunda Guerra Mundial. No final dessa parte do livro, a romancista procurou retratar a comovente relutância dos lituanos que foram forçados a partir abandonando a família e os amigos.

\footnotetext{
4 Havia o tráfico por conta da proibição de se imprimir livros em lituano que havia na época,
} quando apenas se permitia a impressão de livros russos e em alfabeto cirílico. 
Na segunda parte do romance, seu intento foi o de descrever, de um lado, o dia a dia dos descendentes de lituanos que frequentavam a comunidade lituana participando das atividades que então se promoviam e, de outro, mostrar os sacrifícios necessários para o estabelecimento dos lituanos na Austrália, país que, naquela época, meados do século passado, não era acolhedor com os migrantes dos países bálticos os quais eram chamados pejorativamente de "Bloody Balts" e de quem se cobrava que falassem inglês ou que voltassem para onde vieram. Devo esclarecer que o adjetivo bloody pode ser usado em expressões ofensivas que enfatizam a agressividade e o aborrecimento daquele que está falando (SINCLAIR, 1995, p.169).

Circle of Amber é formado por quatro capítulos e dois anexos. No primeiro anexo, há árvores genealógicas das personagens protagonistas e, no segundo, uma coletânea de receitas de pratos dos países bálticos, isto é, relativos à Lituânia, à Letônia e à Estônia. Cada capítulo é nomeado pelo nome da personagem que protagoniza cada parte da trama: Kristina, Renata, Ella e Gaila. Enquanto o primeiro capítulo é ambientado na Lituânia, o segundo transita entre o país báltico e a Austrália e os dois últimos se passam, majoritariamente, na Austrália. No final do Romance, contudo, há cenas 
que se passam na Lituânia, pois o enredo termina com o fim da viagem de Gaila ao país de seus antepassados. Os capítulos são desiguais: o primeiro tem 75 páginas, o segundo com 67 páginas, o terceiro tem apenas 19 páginas e o último é o mais longo de todos, com 129 páginas.

A trama começa in media res. No começo do inverno, em Ventuva, Kristina está preparando o jantar e observa seu gato enquanto rala as batatas para preparar um prato típico lituano chamado pelos samogitas (região norte da lituana onde se fala um dialeto da língua lituana) kleckai ${ }^{5}$. Ela sente um calafrio e tem um mau pressentimento. Para saber o destino, ela faz um ritual com um colar com um pendente de âmbar e uma evocação para consultar os espíritos dos antepassados os quais respondem do interior da Floresta Nebulosa de Pinheiros: "Beware! Take care! Three revolutions are in the air!"6 ( REILLY, 2016, p.10).

A resposta dos espíritos ancestrais é uma chave para a parte histórica do enredo, pois faz referências a três momentos importantes da história da Lituânia. A primeira revolução aludida ocorreu após a primeira guerra mundial

5 Hoje em dia este prato se chama cepelinai (o "ai", se pronuncia "e"), trata-se de um bolinho de batata cozido recheado com carne de porco ou de gado e servido com creme de leite, a receita deste prato está no segundo anexo do romance.

"Fique atenta, tome cuidado, há três revoluções no ar". 
e resultou na independência da Lituânia do czarismo russo (que se havia iniciado em 1795), a segunda se refere à revolução de 1940 que tornou a Lituânia uma república soviética e a terceira se refere à restauração da independência lituana do domínio soviético em 1990 (KONDRATAS; KONDRATAS, 2013, p.26).

A consulta aos espíritos ancestrais se repete em outros momentos da narrativa. Outra consulta é feita no momento em que todos na vila estão tentando apagar um incêndio que atinge a casa da mãe de Kristina, inclusive Jonas ${ }^{7}$ Malkas, o segundo marido de Kristina com quem ela se casou depois do assassinato do seu primeiro marido. Mas, desta vez, ela não consegue nenhuma resposta e pensa que os espíritos estavam muito ocupados com coisas mais importantes (REILLY, 2016, p.72). Apesar dos esforços de todos, o incêndio destruiu muitas casas, inclusive a da mãe de Kristina, Elena, que morre carbonizada.

Mais adiante na narrativa, Kristina novamente consulta os ancestrais. Neste ponto da narrativa, suas filhas, genros e netos acabaram de fugir da guerra e entrar no vagão que os levara para fora do país, ela está angustiada, pois ela não sabe se irão sobreviver, nem como ela conseguirá

7 Este nome pronuncia-se "Ionas" pois na língua lituana a letra "j" não é uma consoante, mas uma semi-vogal. 
viver sozinha com seus mais de oitenta anos de idade. Seu chamado é logo atendido: "A stillness descended around her. Not one tree swayed, no birds sang. She heard Vèjas, the Wind God whisper to her from beyond the pine trees, 'Linden tree, never fear, for I will speed your daughter, far, far from here!"8 (REILLY, 2016, p.131).

No começo, ela interpreta mal a resposta dos espíritos e entende que apenas uma de suas filhas sobreviveria, contudo, o real sentido da mensagem é o de que apenas uma delas ficará longe dela. Ao mesmo tempo em que ouve os espíritos, sua filha Virginia decide voltar para cuidar da mãe, e sua outra filha Renata e a família dela continuam a viagem.

Meses depois da partida de Renata, Kristina - que era parteira - tinha acabado de ajudar a filha adotiva Júlia no parto. O bebê estava na posição errada e nasceu morto. Renata o enterra aos pés de um carvalho e invoca os espíritos desejando que eles livrem sua filha de mais pesares. Renata sente uma forte lufada de ar nas costas e a obtém a seguinte resposta: " $A$ singing revolution with three nations linking hands, will drive the tyrants from our lands" 9 (REILLY, 2016, p.135).

8 "O silêncio se abateu sobre ela. Nenhuma árvore balançava, nenhum pássaro cantava. Ela ouviu, Vejjas, o deus do Vento suspirar-Ihe para além dos pinheiros: "Árvore de Tília, nunca temas pois eu rapidamente vou levar sua filha para longe, para bem longe daqui!".

9 "Uma revolução cantada por três nações de mãos dadas vão tirar os tiranos de nossas terras". 
Esta mensagem é recebida ao mesmo tempo em que sua filha Renata, seu genro e seus netos estão fugindo da perseguição política dos soviéticos ao final da década de 1940, e faz clara referência aos movimentos políticos que resultaram na restauração da independência da Lituânia em 1990, especialmente, ao evento que ficou conhecido como caminho báltico:

At 7:00 p.m. on 23 August 1989, the populations of the three Baltic States staged a protest campaign called the Baltic Way to mark the $50^{\text {th }}$. anniversary of the signing of the Molotov-Ribbentrop Pact. The campaign attracted about two million Lithuanians, Latvians and Estonians who joined hands in a $670-\mathrm{km}$ human chain from the Gediminas Tower in Vilnius to Tall Hermann Tower in Tallinn ${ }^{10}$. (KONDRATAS; KONDRATAS, 2015, p.286)

A última evocação aos espíritos encerra o romance e é feita por Gaila, neta de Renata e bisneta de Kristina. Ela havia procurado um psicólogo, pois estava tendo, repetidamente, um pesadelo no qual está num incêndio. O psicólogo a hipnotiza. Sob estado hipnótico, ela consegue narrar o pesadelo, narrativa que foi gravada numa fita cassete.

10 Às 19:00 do dia 23 de agosto de 1898, as populações dos três estados bálticos planejaram um evento de protesto chamado o Caminho Báltico como um marco do aniversário de 20 anos da assinatura do Pacto Molotov-Ribbentrop. O evento atraiu cerca de dois milhões de lituanos, letos e estonianos que se deram às mãos formando uma corrente humana de 670 quilômetros da Torre de Gedminas em Vilnius até a Alta Torre de Hermann em Tallinn. 
Para surpresa de todos, a audição da fita revela que ela estava falando numa língua desconhecida, mas que parecia familiar por parecer com o idioma lituana que ela aprendera na escola de língua lituana.

As pessoas mais velhas da comunidade lituana da Austrália conseguiram traduzir o texto, que estava no dialeto samogita. O texto é um conjunto de falas de uma mulher que morreu incendiada. Suas falas revelam quem foi responsável pelo incêndio: Vlad a mesma personagem suspeita de ter assassinado o primeiro esposo de Kristina. Uma das falas indicia quem está falando: "What's my daugther Kristina got to do with it?" (REILLY, 2016, p.294). Em minha tradução livre, "O que minha filha Kristina tem a ver com isso?".

A explicação dada pelo psicólogo é a de que Gaila é uma reencarnação da mãe de Kristina e os pesadelos são lembranças do momento em que ela morreu. Trata-se de uma cena que esclarece o mistério da morte da mãe de Kristina, reata o fio de toda a narrativa e torna pleno de significado o nome do livro: Circle de Amber (Círculo de Âmbar).

Um pouco antes de a narrativa ser traduzida, Gaila recebe, da Lituânia, uma carta de uma prima chamada Dana que a convida a conhecer a terra de seus antepassados. Anos mais tarde, ela vai ao encontro da prima de quem recebe 
o pendente de âmbar que era de Kristina e um papel escrito. Nesse papel, Kristina escreve que o pendente deve ser dado para sua bisneta Gaila e dá as instruções para ela consultar os espíritos com ao amuleto. Gaila pega o pendente e lê os dizeres em voz baixa, para si mesma, evocação que encerra o romance: "Turn circle turn, turn to the East. Turn circle turn, turn to the West. Turn circle turn, turn to the North. Turn circle turn, turn to the South" 11 (REILLY, 206, p.301). Descrito o fio da narrativa pela busca das menções ao uso do colar com o pendente de âmbar, descrevo brevemente a organização do romance e seu enredo.

Os eventos narrados no capítulo Kristina começam, provavelmente, vinte anos depois do Levante popular contra o czar russo Alexander II, em 1863, personagem histórica mencionada quando a narradora comenta que dois tios de Kristina tinham morrido neste embate (REILLY, 2016, p.62). Ao longo do capítulo, o marido de Kristina é assassinado e um parto mal sucedido feito por ela resulta na morte da mãe, sua vizinha, o pai abandona o bebê e vai para os Estados Unidos, e ela adota a criança que recebe o nome de Julia. Kristina se casa novamente, as filhas (Virginia, Renata e Julia) crescem e Renata se casa, casamento celebrado em decorrência de ela ter engravidado de seu primeiro namorado.

11 "Vire círculo, vire para o leste. Vire círculo, vire para o oeste, vire para o norte. Vire círculo, vire, vire para o Sul". 
O capítulo Renata começa com a independência da Lituânia do czarismo russo em 1918 e se passa em Palanga onde Renata passa a viver com o seu marido Petras Baras. $\mathrm{O}$ fio da narrativa acompanha essa personagem que tem um casamento infeliz, porém materialmente próspero, e dois filhos, Simas - preferido pelo pai - e Ella - por ele preterida. Quando houve a ocupação alemã da região na Segunda Guerra Mundial entre 1941 e 1944, Petras é obrigado a acolher, em sua casa, generais e soldados alemães. Quando a região é tomada pelos soviéticos, a família retorna para Ventuva onde, por algum tempo, Petras participa das atividades do exército de resistência lituana. Esse exército foi atuante entre 1944 a 1954 e agiu clandestinamente nas florestas por cerca de 10 anos, ficou conhecido como os Irmãos da Floresta e tinha o apoio da população local que Ihes enviava comida secretamente, muitos foram mortos em combate ou foram presos pelos soviéticos, havia inclusive mulheres que militavam nesse exército. (KONDRATAS, KONDRATAS, 2015, p.250-256).

Com a ocupação soviética avançando não restou à família outra opção a não ser sair do país. Renata busca as irmãs dela para todos saírem do país, mas elas mudam de ideia no meio do caminho e preferem retornar para não deixarem 
a mãe sozinha. Narra-se, então, como a família de Renata se deslocou até a Alemanha, onde a família viveu por algum tempo até conseguirem embarcar para a Austrália. Descrevese como foi a viagem e os primeiros anos na Austrália, onde o governo australiano Ihes impôs seus primeiros empregos como faxineiros de um hospital.

Uma série de cartas com notícias dos parentes muda o foco da narrativa para Julia, que adoecera gravemente, mas milagrosamente não falece e recebe um pedido de casamento. Este foi outro milagre para época, considerando que, alguns anos antes, Julia havia engravidado de seu namorado, um soldado partisano conhecido por seu nome de guerra: Eagle Eye, olho de águia, gravidez que havia sido escondida de todos. Esse pedido de casamento encerra o capítulo.

O capítulo seguinte é o mais curto, Ella conta com menos de vinte páginas. Começa com a descrição de como Ella e seu futuro esposo Algimantas Kelmas se conhecem. Ella engravida do namorado e se vê obrigada a casar. Desta gravidez, nasce Gaila; anos mais tarde, nascem seus irmãos Paul e Max. Esta parte da narrativa foca a adaptação da família ao novo país: o período no qual os pais de Gaila trabalharam no hospital e termina com a descrição da reação de Renata ao saber 
que seu marido a traia com sua amiga Ágata e de como ela se viu a si mesma como uma mulher envelhecida e triste.

O último capítulo, Gaila, é o mais longo e tem por foco a descrição da vida da protagonista desde a infância até o final de uma viagem que faz à Lituânia na década de 1990, quando já é avô com cerca de 60 anos de idade.

Jura classifica sua obra como sendo um romance histórico, o que se justifica não só pelo enredo da parte do romance ambientada na Lituânia, mas também nos capítulos finais que se passam na Austrália os quais podem ser vistos como registros da história da migração lituana naquele país. Não obstante esta possibilidade classificatória, sua obra pode receber outras leituras e interpretações, no caso específico deste artigo, retomo cenas e falas que simbolizam ou representam deslocamentos identitários relacionados pela nomeação ou renomeação das personagens. Este recorte da narrativa apresenta semelhanças com o gênero romance de migração.

\section{OS DESLOCAMENTOS IDENTITÁRIOS DAS PERSONAGENS REPRESENTADOS PELAS (RE)NOMEAÇÕES}

A temática do deslocamento identitário permeia a parte do romance ambientada na Austrália e se destaca nas cenas em que há nomeação e renomeações de quatro personagens específicas: Ella, Algimantas Kelmas, Ernestas e Gaila Kelmas. 
A primeira personagem afligida por deslocamentos é Ella, filha de Renata e Petras Baras. Ao nascer, ela já tem sua identidade contestada pelo pai, o qual não a reconhece como filha por achar que ela não tem qualquer semelhança com ele ou com sua esposa, uma vez que a bebê apresenta traços tártaros por ter cabelos e/ou olhos escuros e maças do rosto altas, e desconfia que a bebê seja filha da esposa com outro homem.

Ao ver o bebê, Petras diz: "By the devil! What an ugly kid! She looks nothing like you or me! You've been playing around behind my back, haven't you?" (...) Well, you tell me why this kid's got high cheekbones and black hair like a bloody Tatar." 12 (REILLY, 2016, p.103). Em vão, sua esposa Ihe explica que algum ascendente das famílias deveria ser de origem tártara. Nada disso o faz mudar de ideia. Ella foi sempre por ele relegada, ele sempre como se tivesse um único filho: Simas.

Para entender a argumentação de Renata é preciso levar em consideração a presença e contribuição dos tártaros na história medieval lituana. Os tártaros são descendentes do Império dos Mongóis e começaram a habitar a Lituânia no começo do século XIV durante o Grão-Ducado da Lituânia. Ao final do mesmo século, outra leva de tártaros chegou

12 "Com os diabos! Que criança feia! Ela não se parece em nada, nem comigo, nem com você! Você andou pulando a cerca nas minhas costas, não foi? (...) Bem, então, me diga você, porque esta criança tem maças do rosto altas e cabelo preto como um tártaro de merda!". 
ao país por convite de Vitautas, o grande. Mais tarde, a partir da Batalha de Grünwald ocorrida em 1410 uma cavalaria tártara foi organizada e participou de todas as batalhas importantes do período Lituano-Polonês (KONDATRA, KONDRATRA, 2015, p.48-53).

Como se percebe, a presença dos tártaros é muita antiga, e qualquer dos lados da família poderia ter algum antepassado dessa etnia, porém, mais provavelmente do lado paterno, haja vista que Petras Baras se considera descendentes de famílias nobres (REILLY, 2016, p.85) e os tártaros pertenciam à nobreza militar medieval.

Corroborando sua condição de marginalizada, deslocada dentro da família, seu nome não é um nome de origem lituana (Gaila), latina (Elena, Renata) ou cristão (Kristina) como é o caso das demais protagonistas. O prenome Ella faz parte do repertório de prenomes ingleses, e seu significado converge com a caracterização e o destino da personagem. Ella é um nome relacionado ao nome Alia, cujo significado é "outro", exatamente o que a personagem é para o seu pai, que a relega como filha. Muitos anos mais tarde, ela descobre que o marido a trai com a esposa de um amigo dele chamada Elvyra, ou seja, como mulher casada, ela continuou a ser a outra, a desprezada: 
'I bet that good for nothing husband of yours is playing a round again!'. It's worse this time Mama. Do you remember Elvyra? The one whose first husband was killed in that awful train accident a few years ago?'. 'What about here?'. 'One of the choir ladies told me that she d'seen Al and Elvyra getting out of her red sports car at two in the morning and going into her flat. ${ }^{13}$ (REILLY, 2016, p.200)

Retomo agora um momento anterior da narrativa, quando Ella conhece o homem que seria seu futuro esposo, um rapaz também lituano e refugiado da Segunda Guerra Mundial, na Austrália, durante um festival de dança folclórica lituana. Depois de uma conversa inicial, ele acende um cigarro e assim a ela se apresenta: "I suppose that we should introduce ourselves. My name's Algimantas Kelmas, but my workmates insist on referring to me as $\mathrm{Al}$ Kelm. They say it's much easier. Oh well, we're in Australia now." ${ }^{14}$ (REILLY, 2016, p.153).

A fala de Algimantas indicia uma das mudanças implicadas na migração forçada a que foi submetido: a aceitação de um apelido no lugar do nome próprio, aquele que the fora atribuído por seus pais. O nome de uma pessoa é como um cartão de visita para a interação social: a ele podem ser

13 Eu aposto que o seu marido inútil está pulando a cerca de novo. Desta vez é pior mamãe. Você se lembra da Elvyra? Aquela cujo primeiro marido foi morto naquele acidente horrível alguns anos atrás? Sim, o que houve com ela? Uma das senhoras do coral me contou que viu Al e Elvyra saindo do carro esportivo vermelho dela às duas da madrugada indo ao apartamento dela.

14 Acho que devemos nos apresentar. Meu nome é Algimantas Kelmas, mas os meus colegas insistem em me chamar de $A l$ Kelm. Eles dizem é mais fácil para eles. Bom, nós estamos na Austrália agora. 
atribuídas várias conotações sociais, positivas ou negativas. $A$ fala do marido de Ella revela que o seu nome foi recebido com estranhamento, possivelmente motivado por seu nome não ter equivalente nem na língua inglesa, nem em outras línguas. Não haveria tanto estranhamento se o seu nome fosse de origem cristã, caso em que teria equivalentes. Um exemplo de nome de origem cristã com formas equivalentes nas línguas europeias é o nome Pedro cujo equivalente em lituano é Petras, em francês Pierre e em inglês Peter.

Além de não ter equivalente em outras línguas, o nome Algimantas é um nome cuja pronúncia é difícil para falantes de inglês: a letra "a", por exemplo, soa como em português e não como "ei" e a sílaba tônica do nome "man" também poderia ser de difícil pronúncia para um anglófono. Todas essas dificuldades foram suprimidas mudando-se a forma como o personagem é chamado pelos outros, em público: por um hipocorístico (forma abreviada de um nome) existente na língua inglesa. Na língua lituana, também há hipocorísticos. O hipocorístico Algis é o hipocorístico lituano mais frequente para Algimantas.

No caso dessa personagem, seu sobrenome também foi adaptado pela supressão da terminação do sobrenome " $a s^{\prime}$ a qual, na língua lituana, é uma declinação de gênero masculino, no singular no caso nominativo, como também é o caso 
do substantivo comum darbas (o trabalho) (AMBRAZAS et.al., 1997, p.99-100). A supressão dessas marcas linguísticas torna o sobrenome homônimo ao sobrenome de origem alemã Kelm. Ao ser identificado com outro nome (hipocorístico de prenomes ingleses que começam com Al como Albert, por exemplo) e outro sobrenome (de étimo germânico), ele se torna outra pessoa, pois, nesse novo modo de ser chamado, não há nada que o relacione com o país de onde ele veio, resultando no apagamento de sua origem.

Anos mais tarde, o marido de Ella se acidenta e quebra uma perna enquanto ia ao trabalho. Depois de ser socorrido é internado e compartilha um quarto no ambulatório do hospital com um australiano nativo. A conversa entabulada entre eles é representativa dos deslocamentos espaciais, linguísticos e culturais que ocorrem em contextos migratórios.

Ao apresentar-se ao australiano, o lituano diz seu nome e, logo em seguida informa o seu apelido para facilitar a interação entre eles: "My name's Algimantas Kelmas, but just call me Al. Everyone else does. Told me my name was too hard for them to pronounce!" ${ }^{15}$ (REILLY, 2016, p.166).

Confirma-se, por essa fala, que a mudança da forma de chamamento da personagem não foi feita por iniciativa dele: foram seus interlocutores que começaram a chamá-lo de Al.

15 "Meu nome é Algimantas Kelmas, mas pode me chamar de Al. É como todos me chamam. Me disseram que o meu nome era muito difícil para eles pronunciarem". 
Ao ser chamado assim, o migrante estrangeiro sofre uma espécie de domesticação que o torna menos estranho, mais palatável, mais adaptado à língua, à cultura e aos valores australianos. Ao apresentar-se com esse apelido ao australiano, a personagem revela ter sensibilidade necessária para adaptar-se ao país de acolhida.

Ao ser questionado sobre de onde era, $A /$ responde que é lituano. $O$ interlocutor ouve mal as palavras de $A /$ e entende que ele dissera ser luterano e afirma ser anglicano. Ele esclarece de onde vem, mas o australiano não sabe onde fica a Lituânia ao que Al explica-Ihe que seu país de origem fica perto da Polônia: "I'm Lithuanian... 'So you're Lutheran? I'm an Anglican myself'. No, I mean I come from Lithuania'. 'Where's that?.It is next to Poland" ${ }^{16}$ (REILLY, 2016, p.167).

Percebe-se, pelas falas do interlocutor, que ele nada sabia sobre os lituanos ou a Lituânia. Ao que tudo indica ele ouviu a palavra 'lituano' pela primeira vez na vida, motivo pelo qual acredita ter ouvido outra palavra, o adjetivo "luterano", item vocabular foneticamente semelhante à dita por seu interlocutor.

Devo informar que, no dia em que $A /$ se encontra com Ella pela primeira vez, sua futura esposa narra-lhe como a família de Renata chegou à Austrália. Sua fala revela como, para ela, o país de acolhida era-lhe um lugar totalmente desconhecido:

16 "Eu sou lituano. Então, você é luterano? Eu mesmo sou anglicano. Não, eu quis dizer que eu vim da Lituânia. Onde fica isto? Perto da Polônia". 
"I was glad when we finally docked in Melbourne (...) But it was freezing cold. No one told us that the seasons were all upside down here, compared to Lithuania. I trade my fur coat for a bag of bananas in Africa, I can't believe that I was so stupid." ${ }^{17}$ (REILLY, 2016, p.158-159).

Os deslocamentos indiciados pelo nome e pelo modo como são chamadas as personagens são também evidenciados pela história de Gaila (este nome se pronuncia como uma oxítona, a última sílaba é a tônica). Ela é a filha mais velha de Al e Ella. O casamento deles foi consequência dessa gravidez ocorrida nos primeiros meses de namoro. Sobre a escolha desse nome, a reação de Renata, mãe de Ella é reveladora:

Six months later when Ella gave birth to a little baby girl with a fuzz of white blonde hair, whom she decided to name "Gaila". Renata kept on knitting baby clothes and made no comment that the child's name meant "sorrow". She just remarked that the baby looked like her when she was born, apart form her hair and skin ${ }^{18}$ (REILLY, 2016, p.164).

O pensamento de Renata sobre o nome da neta pode ser interpretado ao menos de duas maneiras. A escolha do nome se pauta pelo seu significado e revela os valores,

17 "Eu fiquei feliz quando desembarcamos em Melobourne (...). Mas estava congelando de frio. Ninguém tinha nos dito que as estações do ano eram invertidas em comparação com a Lituânia. Eu troquei meu casaco de pele por um cacho de bananas, não consigo acreditar que eu fui tão burra."

18 Seis meses mais tarde, foi quando Ella deu à luz a uma bebezinha com uma penugem de cabelo branco de tão louro, a quem ela decidiu nomear de "Gaila". Renata continuou tricotando as roupas do bebê e não fez nenhum comentário sobre o fato de o nome do bebê significar "pesar". Ela apenas comentou que o bebê se parecia com ela, a não ser pela cor da pele e do cabelo... 
pensamentos ou sentimentos de quem escolheu o nome. Desse ponto de vista, chamar a filha de Gaila indicia o modo como a mãe se sentiu quando engravidou, tendo sido, por isso, obrigada a se casar: com pesar. Outra possibilidade é a de o significado do nome conter em si o destino ou a personalidade do portador, neste caso receber um nome assim é uma maldição, pois traria à menina um destino cheio de pesares. Devo informar que este modo de nomear não foi seguido quando nasceram os seus dois irmãos os quais, ao contrário dela, receberam nomes ingleses: Paul e Max.

Essa última interpretação converge com boa parte das peripécias de Gaila, eis alguns exemplos: quando tinha sete anos, por duas vezes, ela ficou totalmente arranhada quando brincava com gatos; depois quando, pela primeira vez, foi lhe permitido visitar um vizinha de família estoniana, ela tentou brincar com o cachorro o qual por ter sido treinado na língua estoniana não entendeu o que ela lhe dizia em lituano e a atacou. No começo da adolescência, seu pai suspeitou de um namorico dela com um primo de segundo grau e the cortou os lindos cabelos. Anos mais tarde, aos 20 anos, ela faz sua primeira viagem ao exterior e é roubada. Apenas dois eventos de sua vida foram realmente positivos: seu casamento, em todo o romance apenas ela e Kristina tem casamentos felizes, e o desfecho de sua história ao final do romance. 
No contexto do romance, num momento anterior ao da nomeação de Gaila, há menção à crença de que o nome de uma pessoa revela sua personalidade. Quando Kristina sabe que Renata está grávida de Petras Baras, ficando obrigada a se casar com ele, sua mãe faz um comentário e elas tem a seguinte conversa:

Renata, now tell me the truth. Are you absolutely sure that you wish to marry Petras? You know he's the first man who's ever paid any attention to you.And remember what people say.Baras by name, baras by nature.'. 'What has Petra's surname got to do with what sort of man he is? retorted Renata.'That's just one of your silly pagan superstitions. Yes mama, I am well aware that his surname means a tavern, but he's not a drinker (...). ${ }^{19}$ (REILLY, 2016, p.90)

Voltando à história de Gaila, quando ela começar a frequentar a escola, ela enfrenta dificuldades por não saber a língua inglesa e, ao se sentir tão deslocada, deseja ter outra identidade:

Gaila constantly wished that she wasn't the child of refugees who had to flee from the terrors of Stalin, Siberia ${ }^{20}$, Hitler and the Holocaust. As it was, once she started school she couldn't speak a word of English.

19 Agora, Renata, me conta a verdade. Você tem mesmo certeza que quer se casar com Petras? Você sabe que ele foi o primeiro homem que te deu atenção. E se lembre do que as pessoas falam. Baras por nome, baras por natureza. O que o sobrenome de Petra tem a ver com o tipo de homem que ele é? contestou Renata. Isto é apenas uma de suas tolas superstições pagãs. Sim mamãe, eu si bem que o sobrenome significa um bar, mas ele não é um bêbado. (...)

20 Como o pai de Gaila se envolveu no movimento dos partisans, toda a família seria deportada para lá caso não fugissem do país. 
She soon learnt because there was no other option $^{21}$. (REILLY, 2016, p.173)

Portar um nome que está num idioma, num país em que se fala outro como língua oficial pode funcionar como um obstáculo. Este foi o caso do pai de Gaila. Essa dificuldade também foi sentida por um primo distante o qual ela (re) encontra num acampamento de escoteiros aonde ela vai aos doze anos de idade: "Hey you! Why do you keep staring at me all the time? 'Ah, um, is your name Galia Kelmas? Yes, so what's it to you? I think that you're my cousin! The boy stammered holding out a faded black and white photo." 22 (REILLY, 2016, p.184).

Esta é a primeira vez, no romance, em que o nome completo de Gaila é mencionado. O sobrenome dela mostra ter havido um deslocamento do idioma lituano para o idioma do país de chegada dos migrantes, uma mudança ocorrida também quando os migrantes lituanos chegaram ao Brasil (SEIDE, 2018a). No idioma lituano, os sobrenomes das mulheres têm terminações específicas para indicar se a pessoa é solteira ou casada.

21 Gaila constantemente desejava não ser filha de refugiados que fugiram dos terrores de Stalin, da Sibéria, de Hitler e do Holocausto. Mas, como ela era, quando começou a ir à escola, não conseguia falar uma palavra em inglês. Ela logo aprendeu, já que não tinha outra escolha.

22 Ei,você! Por que você fica olhando para mim o tempo todo? Ah, hum, o seu nome é Galia Kelmas? Sim e dai? Eu acho que você é minha prima! Gaguejou o garoto, segurando uma foto desbotada em preto e branco. 
De acordo com o sistema antroponímico lituano, o sobrenome de uma mulher solteira deve apresentar uma das seguintes terminações: sobrenome termina em -aitè, -ytè, -utè, ou -iūte. Se a mulher é casada, ela recebe o sobrenome do marido, o qual deve apresentar a terminação -ienè" (DŽEŽULSKIENE், 2014, p.19). Logo, segundo as regras do idioma lituano, seu nome completo seria Gaila Kilmaitè. Contudo, ao ser registrado na língua oficial do país, foram seguidas as regras linguísticas da língua inglesa e ela herdou o sobrenome de seu pai sem qualquer modificação: Kelmas.

Voltando à cena de reencontro dos primos, o garoto se apresenta a Gaila dizendo: '(...) my name is Rokas.' 'Rokas? Is that Lithuanian?. 'Actually my parents gave me a lithonameErnestas'. (...) I got called "Ernie" at school, till I changed it to Rokas." ${ }^{23}$ (REILLY, 2016, p.186).

No caso do nome do primo, Ernestas (em português Ernesto), há um nome equivalente em inglês cujo hipocorístico é escolhido pelos colegas do primo como forma de chamamento dele. Por não aceitar esse apelido, ele cria um pseudônimo o qual é aceito publicamente e ele passa a chamar-se e ser chamado por ele. Representase nesse trecho uma solução diferente das já apresentadas

23 (...) meu nome é Rokas. Rokas? Isto é lituano? Na verdade, meus pais me deram um nome litho - Ernestas. (...) eu era chamado "Ernie" na escola, até que eu mudei meu nome para Rokas. 
para o conflito identitário subjacente à questão de como ser chamado: enquanto Algimantas adota o apelido a ele atribuído - Al - Ernestas cria para si uma maneira alternativa de ser chamado.

Mais adiante no romance, é descrita uma parte de uma aula em que Gaila é assediada pelos colegas do ensino médio. Ela tenta ler, a pedido da professora, sua redação sobre o tema do uso do uniforme na escola. Um dos argumentos citados por ela - o de que usar a mesma roupa é um modo de fazer os estudantes se sentirem iguais uns aos outros poderia se aplicar a ela mesma, tendo em vista sua classe social e sua origem migrante.

Por conta disso, um dos colegas fala em voz alta, interrompendo a leitura que Gaila estava fazendo: "'(...), you d'know of course, wouldn't ya, you stupid galah,' sniggered Sharon, the class bully". Gaila went beetroot red. She hated the way that she made fun of her name. She was going to shorten it to "Gail", as soon as she could." 24 (REILLY, 2016, p.191).

Na minha tradução, não consegui manter o trocadilho que existe no original. Em inglês, a palavra galah-cuja pronúncia é praticamente idêntica à pronúncia lituana do nome Gaila -, em sua acepção original, nomeia um pássaro australiano

24 Ah, você sabe exatamente como é isso né', sua burra estúpida, disse rindo Sharon, a valentona da turma. Gaila ficou vermelha como uma beterraba. Ela odiava o modo como faziam piada com o nome dela. Ela ia abreviar o nome para Gail o quanto antes. 
que, em língua portuguesa, se chama cacatua. A segunda acepção da palavra é exclusiva do inglês australiano: tratase de uma palavra pejorativa utilizada para dizer que uma pessoa não é nada inteligente. Para manter a metáfora zoonímica, traduzi "stupid galah" para "burra estúpida". Considerando a pronúncia dos nomes, percebe-se que, aos ouvidos australianos, o nome Gaila é equiparado ao nome do pássaro socialmente avaliado como tolo. O trocadilho vem desta semelhança fonética.

Para se livrar desse trocadilho infame, Gaila pensa que, dando para si mesma o pseudônimo Gail, se livrará do tormento de ser ridicularizada pelos colegas. Gail é a forma abreviada de Abgail. Por ironia, o significado etimológico de Abgail é "alegria do pai" exatamente o significado inverso que tem o nome Gaila no idioma lituano e no contexto do romance considerando que ela foi fruto de uma gravidez indesejada.

Ao final da aula, Sharon the dá um empurrão de propósito e the diz "Sorry Gay-lah", pronunciando seu nome como se ele fosse o nome inglês "Gaila" . Ainda no mesmo dia colaram nas suas costas um papel onde estava escrito: "Gaila the galah is a bitch" 25 (REILLY, 2016, p.191).

25 Gaila, a burra, é uma puta. 
O assédio que sofria também partia de um de seus professores, o de Matemática, que pronunciou equivocadamente o seu nome, dando oportunidade para mais um evento de assédio moral: "The worst offender was her Maths teacher, Mr.Bench. When he went through roll call in her first year at high school, he called out 'Galah kelmass!' From then on the teasing began,' Galah, Galah where's your ass?" 26 (REILLY, 2016, p.192).

Nesse trecho, além do trocadilho com o nome Gaila já esclarecido, há o trocadilho com o seu sobrenome. O professor pronuncia o nome com como se fosse formado por duas palavras: kelm e ass. A primeira "palavra" corresponde ao sobrenome de origem alemã Kelm. Já a segunda corresponde à palavra de baixo calão "ass" que significa "bunda".

Ao final do romance, há uma cena em que ela atende ao telefone e se identifica não com seu nome oficial, mas sim com o pseudônimo por ela escolhido, seguido do sobrenome do marido indicando que ela adotou para si uma forma alternativa de chamamento, como o fizera Ernestas, seu primo, cumprindo, portanto, a promessa que se fizer era uma aluna colegial: 'Is that Mrs.Ella Kelmas? No, it's her daughter Gail Smythe" 27 (REILLY, 2016, p.280).

26 Seu pior ofensor era o professor de Matemática, o Senhor Bench. Quando ele começou a chamada, no primeiro ano do colégio, ele falou em alta voz Galah kelmass! Daquele dia em diante, começou a provocação: Galah, galah onde está o seu traseiro?

27 A senhora Ella Kelmas está? Não, quem fala é sua filha Gail Smythe". 


\section{CONSIDERAÇÕES FINAIS}

Ernestas recebera dos amigos não lituanos o apelido Ernie, hipocorístico da língua inglesa do seu nome completo. Não aceitando esse apelido, criou um nome para si, pseudônimo que foi aceito socialmente. Algimantas também recebeu um apelido que é um hipocorístico da língua inglesa: $A I$. Diferente do adolescente Ernestas, o apelido acabou sendo aceito, tendo sido adotado em todos os âmbitos de interação. Em ambos os casos, apesar de a reação pessoal ter variado, aconteceu o mesmo deslocamento identitário causado pelo apagamento da origem étnica dos nomeados, invisibilidade ainda maior no caso de Algimantas, que recebera de seus pais um nome exclusivamente lituano.

O deslocamento de Ella, por sua vez, não ocorreu por conta da migração, mas sim pelo significado de seu nome que the marcou o destino. Chama a atenção o nome ser de origem inglesa e não lituana ou latina. Esse nome segue outro padrão, se bem clássico no romance tradicional de língua inglesa no qual o nome da personagem prenuncia o que the ocorrerá. Seu pai a considerou excluída de seu grupo familiar por causa de sua aparência tártara a qual indicaria que ela seria uma filha bastarda, já que só poderia ser filha de outro pai. O significado de Ella, etimologicamente, 
"a outra", converge com o pensamento do pai a respeito dela quando ela nasceu. Em sua vida adulta, o marido de Ella teve muitas amantes, e ela se tornou a preterida, a que é traída.

Ter o destino predeterminado também foi a sina de Gaila cuja nomeação foi analisada por sua avó que já lhe previra um triste futuro, segundo crenças lituanas de que o nome pode influenciar a personalidade ou o destino da personagem. $\mathrm{Na}$ língua lituana, Gaila significa "pesar", e sua vida foi repleta de pesares. Como se não bastasse, a pronúncia de seu nome na língua inglesa lembra o nome de um pássaro australiano conhecido por não ser inteligente, a interpretação do nome da personagem como sendo o nome do pássaro de origem a muitos trocadilhos e humilhações na época e que estava no colégio. Para se livrar do trocadilho humilhante, ela adota para si o nome Gail, hipocorístico de Abgail, na língua inglesa.

Enquanto a forma alternativa de chamamento de Algimantas foi imposta e aceita por questões de sobrevivência e adaptação ao novo país pelo migrante lituano que precisava adaptar-se logo e garantir o sustento seu e da família, as formas alternativas dos descendentes de lituanos, Ernestas e Gail foram ativamente buscadas, numa construção performática da identidade tal qual a entende Bauman, numa busca pela igualdade, por ser considerado 
como um par, alguém com os mesmos direitos dos outros jovens australianos, um esforço necessário para passar a fazer parte do grupo dos estabelecidos, daqueles que tem prestígio social como explicam Elias e Scotson.

Considerando as mudanças relacionadas à (re)nomeação e a noção de identidade como algo pelo qual se luta, mas que depende, em última instância, de como o indivíduo é interpelado na sociedade, é possível vislumbrar dois modos de funcionamento da nomeação em sua representação literária de contexto migratórios: enquanto receber um apelido equivale a receber uma identidade imposta pelo outro, propor um pseudônimo é construir uma nova identidade a ser aceita pelo outro. Em ambos os casos, é preciso abrir mão da identidade existente no país de partida e se reinventar.

A análise ora apresentada, importante ressaltar, não esgota de forma alguma o romance. Por exemplo, Algimantas, em outros aspectos de sua vida, age ativamente para conservar e fomentar sua identidade lituana participando das atividades do comitê da comunidade lituana e sempre prefere comer pratos típicos lituanos. Diferentemente, Gaila, apesar de ter participado das atividades da comunidade e ter aprendido o idioma de seus pais da escola de língua lituana, 
não conservou o hábito de comer os pratos lituanos, não obrigou os seus filhos que teve com o marido australiano (de origem irlandesa) nem a participarem das atividades da comunidade, nem a aprenderem o idioma dos antepassados. Essas informações sobre o enredo do romance indicam que a questão identitária ultrapassa o objeto de estudo deste artigo: a investigação da relação entre identidade, nomeação e renomeação das personagens.

Essa análise da representação literária da nomeação em contexto migratório pode ser relacionada com análises literárias que versam sobre a literatura de imigração seja no Brasil ou no exterior, como é o caso das análises literárias de Oliveira e Carreira sobre a imigração palestina no Brasil na qual se comparam uma obra sobre a imigração escrita por um libanês no Brasil, Salin Miguel e outra escrita por um descendente de libanês no Brasil (OLIVEIRA; CARREIRA, 2011).

Considerando que a literatura australiana é muito divulgada no Brasil e que a migração lituana ter sido minoritária em ambos os países, há outras perspectivas interpretativas que poderiam ser analisadas. Seriam interessantes análises que relacionem a memória coletiva à identidade étnica, que possam evidenciar que a narrativa como meio de salvaguardar a memória coletiva para as gerações mais jovens, aquelas formadas pelos netos e bisnetos de migrantes. 
Outro viés promissor relaciona-se com o da recepção do romance de acordo com o público leitor. Que perspectivas interpretativas surgiriam da leitura da obra por parte de australianos que desconhecem a migração lituana lá? E por parte de brasileiros que pouco sabem sobre os australianos e também ignoram a existência da Lituânia e dos lituanos? E se o público leitor é formado por descendentes de lituanos do Brasil que tem memórias compartilhadas com as das personagens retratadas ao longo do romance de Jura?

Com relação à recepção do romance por descendentes de lituanos do Brasil, devo dizer que, como neta e filha de lituanos, pelo lado paterno, a minha leitura da obra foi pessoal da obra: ela que reavivou memórias esquecidas e atiçou minha imaginação para fatos pretéritos que foram tacitamente silenciados por meus avôs num jogo entre memória, silêncio e esquecimento conforme o descreve Michael Pollak (1989). Meu tataravô (assim como os tios de Kristina) participou do levante contra o tsarismo, meu bisavô (ao contrário de Renata de Petras, mas como Marius, personagem secundária na trama) foi exilado para a Sibéria, um tio-avô se envolveu no movimento partisan e meu avô, como reitor e professor universitário, resistiu ao domínio soviético. Ele e minha avó seriam mortos ou deportados se permanecessem 
na Lituânia (correram o mesmo perigo de que escapou Renata e sua família). Por fim, meu pai aprendeu o idioma oficial do país de acolhida na escola (como Gaila), ainda que não tenha participado com frequência das atividades da comunidade lituana na Vila Zelina, na cidade de São Paulo, não tenha se casado com uma lituana ou descendente de lituano (do mesmo modo que Gaila escolheu para si um marido não lituano ou descendente de lituano) e, também como ela, não tenha obrigado os filhos a aprenderem o idioma lituano e a frequentarem os eventos da comunidade lituana.

Termino meu artigo retomando as palavras de Jura na dedicatória de seu livro na qual ela enfatiza a relação entre literatura, identidade e memória: "This novel is dedicated to my children and grandchildren, so that the may discover more about their Lithuanian heritage." 28 (REILLY, 2016, p.5).

\section{REFERÊNCIAS}

AMBRAZAS, V. et al. (1997). Lithuanian Grammar. Vilnius: Institute of the Lithuanian Language.

BAUMAN, Zygmunt. (2005). Identidade. Entrevista a Benedetto Vecchi. MEDEIROS, C.A. (Trad.) Rio de Janeiro: Zahar.

DŽEŽULSKIENĖ, Judita. (2014). Kalbu Lietuviškai. Lithuanian for beginners. Kaunas:Editora da Universidade Tecnológica de Kaunas.

ELIAS, Norbert; SCOTSON, Jonh, L. (2000) Os estabelecidos e os outsiders. Sociologia das relações de poder a partir de uma pequena comunidade. RIBEIRO, V. (Trad.). Rio de Janeiro: Zahar.

28 Este romance é dedicado aos meus filhos e aos meus netos, para que possam descobrir mais sobre a sua herança lituana. 
HALL, Stuart. (2006). A identidade cultural na pós-modernidade.11.ed. Rio de Janeiro: DP\&A Editora.

OLIVEIRA, Michele Lima de; CARREIRA, Shirley de Souza Gomes (2011). Memória de ficç̧ão: a imigração libanesa revisitada. Revista UniAbeu, Belford Roxo, RJ, 4(7), mar.-ago, 15-37.

POLLAK, Michael (1989). Memória, Esquecimento, Silêncio. Estudos Históricos, Rio de Janeiro, 2(3), 3-15.

KONDRATAS, Skirma; KONDRATAS, Ramūnas (Eds e Trads.) (2015). The history of Lithuania. 2.ed. Vilnius: Eugrimas.

REILLY, Jura. (2016). Circle of Amber, Geelong, Austrália: Geelong writers Inc.

SEIDE, Márcia Sipavicius (2008). "Usos de antropônimos como elementos coesivos". Fórum Linguístico, Florianópolis, (5)2, 23-35.

(2016). "Métodos de pesquisa em Antroponomástica". Domínios de Lingu@gem, 10, 1146-1171.

(2018a). "Antroponímia e imigração: os nomes de brasileiros descendentes de lituano". Sociodialeto, 7, 52 - 81.

(2018b). "Nomeação e territorialização no bairro Vila Zelina em São Paulo, no Brasil". Revista Fórum Identidades, 26, 161-178.

SINCLAIR, Jonh (1995). English Dictionary. Helping learners with real English. Londres: Collins Cobuild.

Marcia Sipavicius Seide é Doutora em Letras (USP, 2006), realizou estágio Pós-Doutorado em Linguística (UFSC, 2015), é docente do Programa de Pós-Graduação em Letras da Universidade do Oeste do Paraná (UNIOESTE) e do Colegiado de Letras da Unioeste, Campus de Marechal Cândido Rondon, é membro efetivo do Grupo de Trabalho da ANPOLL Lexicologia, Lexicografia e Terminologia. 